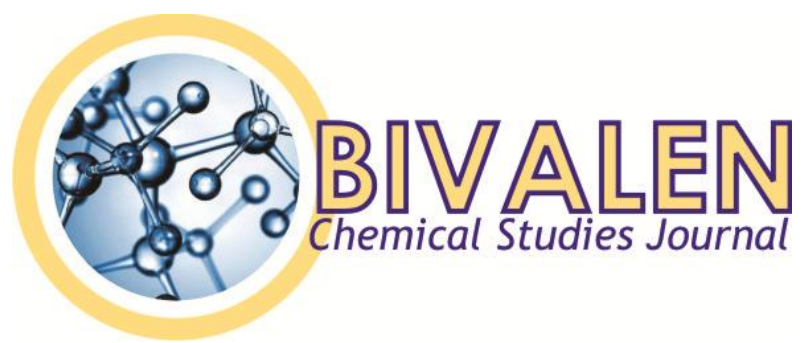

\title{
PERBEDAAN HASIL BELAJAR SISWA SMA YANG DIAJAR MENGGUNAKAN METODE DEMONSTRASI DAN METODE EKSPERIMEN PADA POKOK BAHASAN LARUTAN ELEKTROLIT DAN NONELEKTROLIT THE DIFFERENCE OF SENIOR HIGH SCHOOL STUDENT LEARNING OUTCOMES TAUGHT USING DEMONSTRATION METHOD AND EXPERIMENTAL METHOD ON ELECTROLYTE AND NONELECTROLYTE SOLUTIONS
}

\author{
Syaiful Bahri $^{* 1}$, Mukhamad Nurhadi ${ }^{2}$, Iis Intan Widiyowati ${ }^{1}$ \\ ${ }^{\text {I}}$ Program Studi Sarjana Pendidikan Kimia, Fakultas Keguruan dan Ilmu Pendidikan, Universitas Mulawarman, \\ Samarinda, Kalimantan Timur, Indonesia \\ ${ }^{2}$ Program Studi Pascasarjana Pendidikan Kimia, Fakultas Keguruan dan Ilmu Pendidikan, Universitas \\ Mulawarman, Samarinda, Kalimantan Timur, Indonesia \\ *Corresponding Author: Ifunkk21@gmail.com (+628115571175)
}

\begin{abstract}
ABSTRAK
Penelitian ini bertujuan untuk mengetahui perbedaan hasil belajar siswa SMA yang diajar menggunakan metode demontrasi dan eksperimen pada pokok bahasan larutan elektrolit dan nonelektrolit. Penelitian ini dilaksanakan di SMA Negeri 17 Samarinda, Indonesia. Penelitian ini tergolong quasi experiment dan subjek penelitian ditentukan menggunakan teknik purposive sampling. Dalam penelitian ini terdapat dua kelompok siswa yang diajar menggunakan model pembelajaran explicit instruction; kelompok siswa yang diajar dengan metode eksperimen dan kelompok siswa yang diajar dengan metode demonstrasi. Data dalam penelitian ini berupa dokumentasi, nilai tes kemampuan kognitif dan aktivitas siswa. Data dokumentasi berupa nilai siswa pada pokok bahasan sebelumnya yang digunakan untuk menguji homogenitas subjek penelitian. Nilai tes kemampuan kognitif siswa diperoleh dari masing-masing $30 \%$ nilai posttest pertemuan 1 dan pertemuan 2 serta $40 \%$ nilai ulangan harian. Perbedaan hasil belajar siswa dianalisis menggunakan $t$-test. Hasil penelitian menunjukkan bahwa rata-rata nilai hasil belajar siswa yang diajar menggunakan metode eksperimen adalah 70,3, lebih baik dari hasil belajar siswa yang menggunakan metode demonstrasi yaitu 61,1 pada taraf signifikan 0,05. Hasil ini menunjukkan bahwa terdapat perbedaan signifikan antara hasil belajar siswa yang diajar dengan metode eksperimen dan hasil belajar siswa yang diajar dengan metode demonstrasi.
\end{abstract}

Kata kunci: explicit instruction, eksperimen, demonstrasi, hasil belajar

\section{ABSTRACT}

The aim of study was to find out the difference of senior high school student learning outcomes, especially in the subject of electrolyte and non-electrolyte solutions, taught by using demonstration and experimental method. Research subject of this study was tenth grade students of SMA Negeri 17 Samarinda, Indonesia. Method of this study is a quasi-experiment and the subject was selected by purposive sampling technique. In this study, two groups of students were taught by using explicit instruction model; group of students by using experimental method and group of students taught by using demonstration method. That data in this study were documentation, score of student cognitive achievement and student activities. Documentation data was the previous student learning outcomes and used to determine 
homogeneity of the subjects. The score student cognitive achievements were student learning outcomes that obtained from $30 \%$ of each post-test score of $1^{\text {st }}$ and $2^{\text {nd }}$ lessons, and $40 \%$ of examination score. The difference of student learning outcomes was analyzed using t-test. The result of this study showed that the student learning outcomes taught by using experimental method was 70.3, higher than that of students taught by using demonstration method (61.1). These results indicated that learning outcomes of students taught using by experimental method was significantly different $(\alpha=0.05)$ than that of students taught by using demonstration method.

Keywords: explicit instruction, experimental method, demonstration method

\section{PENDAHULUAN}

Hasil belajar siswa dapat dijadikan sebagai tolak ukur keberhasilan suatu pembelajaran yang dilakukan (Purwatiningsi, 2013). Tingkat pemahaman siswa terhadap materi yang telah diajarkan dapat dilihat dari hasil belajar siswa (Nurcholis, 2013). Pemahaman siswa terhadap suatu materi dipengaruhi oleh minat dan perhatian siswa selama proses pembelajaran (Marsita, Priatmoko, \& Kusuma, 2010). Guru adalah salah satu bagian yang mempengaruhi minat dan perhatian siswa dalam belajar (Aritoanang, 2008). Sebagai fasilitator dalam penyelenggaraan proses belajar siswa (Ardana, Sunasih, \& Ganing, 2014), guru harus mampu menciptakan suasana belajar yang nyaman dan menyenangkan (Aritoanang, 2008). Salah satu cara yang dapat dilakukan oleh seorang guru untuk menciptakan suasana tersebut adalah dengan pemilihan model pembelajaran yang tepat (Sulistiani $\&$ Arif, 2015).

Beberapa penelitian telah dilaporkan bahwa penggunaan model pembelajaran explicit instruction dapat meningkatkan hasil dan prestasi belajar siswa (Megawati, 2016; Sulistiani \& Arif, 2015; Lestari \& Kurjono, 2015; Suroto, 2015; Nur, 2015; Rahmawati, 2016; Jumadi, 2016). Model pembelajaran explicit instruction adalah model yang dirancang khusus untuk menunjang proses belajar siswa yang berkaitan dengan pengetahuan deklaratif dan pengetahuan procedural yang terstruktur dengan baik yang dapat diajarkan dengan pola kegiatan yang bertahap, selangkah demi selangkah. Penerapan model pembelajaran ini menjadikan guru sebagai pusat perhatian siswa selama proses belajar. Siswa akan bereaksi aktif dalam pembelajaran jika guru mampu menjadi daya tarik bagi siswa untuk aktif mendengarkan dan mencatat materi yang disampaikan oleh guru, sehingga hasil belajar siswa di sekolah bisa menjadi lebih baik (Trianto, 2011). Kelemahan model pembelajaran explicit instruction adalah tidak dapat dikembangkannya keterampilan sosial siswa, sehingga guru akan berperan aktif dalam proses pengembangan diri setiap siswa untuk memperoleh hasil yang baik. Untuk lebih mengaktifkan siswa, metode demonstrasi dan eksperimen dapat dijadikan pilihan dalam melaksanakan pembelajaran menggunakan model explicit instruction. Handhika (2010) dan Handa (2013) melaporkan bahwa metode eksperimen dan demonstrasi dapat meningkatkan perhatian dan hasil belajar siswa. Sebagaimana kita ketahui bahwa, keterlibatan siswa dalam proses pembelajaran dengan metode eksperimen lebih tinggi dibandingkan dengan metode demonstrasi. Keterlibatan aktif siswa dalam proses pembelajaran berperan penting dalam mengkontruksi pemahamannya yang berdampak pada hasil belajarnya (Marjan, Arnayan, \& Setiawan, 2014).

Materi larutan elektrolit dan nonelektrolit merupakan salah satu materi kimia yang membutuhkan kendali dari guru terhadap isi materi dan urutan informasi, sehingga dapat mempertahankan fokus mengenai apa yang harus dicapai oleh siswa. Materi ini harus disampaikan secara efektif karena berisi konsep, keterampilanketerampilan eksplisit dan informasi dan pengetahuan faktual yang terstruktur. Materi ini juga membutuhkan pembuktian nyata yang dapat dilakukan dengan demonstrasi atau eksperimen.

Berdasarkan uraian diatas, penelitian ini dilakukan untuk mengetahui perbedaan antara hasil belajar siswa yang diajar menggunakan model pembelajaran explicit instruction dengan metode demonstrasi dan eksperimen pada pokok bahasan larutan elektrolit dan nonelektrolit.

\section{METODE PENELITIAN}

Penelitian ini tergolong penelitian quasi experiment. Penelitian ini dilaksanakan di SMA Negeri 17 Samarinda, Kalimantan Timur, Indonesia, 
pada tahun ajar 2016/2017. Dua kelas dipilih sebagai subjek penelitian melalui purposive sampling; kelompok pertama (32 siswa) diajar dengan menggunakan model pembelajaran explicit instruction dengan metode eksperimen, disebut kelas eksperimen, dan kelompok kedua (32 siswa) diajar dengan model pembelajaran explicit instruction dengan metode demonstrasi, disebut kelas demonstrasi. Pada penelitian ini dibagi menjadi 3 pertemuan; pertemuan pertama membahas pengertian larutan elektrolit dan nonelektrolit, pengelompokan larutan elektrolit dan nonelektrolit, teori Svante Arrhenius, dan pengelompokan larutan elektrolit berdasarkan senyawa ion dan senyawa polar; pertemuan kedua membahas tentang daya hantar listrik larutan elektrolit dan nonelektrolit, serta perbedaan larutan elektrolit kuat dan elektrolit lemah; pertemuan ketiga diisi dengan ulangan harian. Pembelajaran di kedua kelas diawali dengan penyampaian tujuan pembelajaran, pendemonstrasian pengetahuan dan keterampilan, pembimbingan pelatihan, pengecekan pemahaman siswa dan pemberian kesempatan kepada siswa untuk pelatihan lanjutan dan penerapan. Pada tahap pendemonstrasian pengetahuan dan keterampilan; siswa kelas demonstrasi diberikan demonstrasi oleh guru, siswa mengamati dan mencatat fenomena yang terjadi yang kemudian dilakukan diskusi dan pembahasan tentang apa yang diamati oleh siswa; siswa kelas eksperimen melakukan eksperimen dibawah pengawasan guru, mencatat dan mengamati fenomena yang terjadi dan diakhiri dengan diskusi dan pembahasan tentang apa yang diamati siswa dibawah bimbingan guru.

Teknik pengumpulan data terdiri atas dokumentasi dan tes. Data dokumentasi berupa nilai hasil belajar siswa kelas eksperimen dan kelas demonstrasi pada pokok bahasan sebelumnya yang digunakan untuk uji homogenitas kedua subjek penelitian. Berdasarkan hasil uji homogenitas sebagaimana tampak dalam Gambar 1, kedua kelas adalah homogen $(\alpha=0,05)$. Data hasil tes berupa nilai post-test dan ulangan harian. Soal post-test dan soal ulangan harian disajikan dalam bentuk soal pilihan ganda yang dibuat berdasarkan indikator pembelajaran. Nilai post-test dan ulangan harian kemudian diolah menggunakan persamaan (1) untuk mendapatkan nilai hasil belajar siswa, data observasi berupa aktivitas siswa dalam proses belajar mengajar.

$$
\mathrm{HB}=30 \% \mathrm{P}_{1}+30 \% \mathrm{P}_{2}+40 \% \mathrm{UH}
$$

$\mathrm{HB}$ adalah hasil belajar siswa, $\mathrm{P}_{1}$ adalah nilai post-test pertemuan pertama, $\mathrm{P}_{2}$ adalah nilai post-test pertemuan kedua, dan $\mathrm{UH}$ adalah nilai ulangan harian.

Validasi instrumen (soal post-test, soal ulangan harian dan lembar observasi) dalam penelitian ini dengan menggunakan pengujian construct validity dan content validity. Construct validity adalah uji validitas menggunakan pendapat ahli (Sugiono, 2016). Instrumen yang di ujikan ke para ahli berupa 20 soal post-test untuk pertemuan pertama, 20 soal post-test untuk pertemuan kedua, 40 soal untuk ulangan harian dan lembar observasi aktivitas siswa. Validator instrumen dalam penelitian ini adalah 2 dosen di Program Studi Sarjana Pendidikan Kimia, FKIP, Universitas Mulawarman dan 1 guru kimia di SMA Negeri 17 Samarinda. Content validity adalah uji validitas dengan membandingkan antara instrumen dengan materi pelajaran yang telah diajarkan (Sugiono, 2016). Content validity dilakukan di kelas X-3 SMA Negeri 11 Samarinda.

Perbedaan hasil belajar siswa dianalisis menggunakan $t$-test dengan $\alpha=0,05$ (Pramudjono, 2011)

\section{HASIL DAN PEMBAHASAN}

Data nilai siswa kelas eksperimen dan demonstrasi disajikan dalam Gambar 1. Berdasarkan Gambar 1 tampak bahwa nilai rata-rata post-test pertemuan 1 dan 2, nilai rata-rata ulangan harian, dan nilai rata-rata hasil belajar siswa kelas eksperimen lebih tinggi dari siswa kelas demonstrasi. Hasil uji analisis statistik menunjukkan bahwa terdapat perbedaan yang signifikan pada nilai rata-rata siswa kelas eksperimen dan demonstrasi. baik untuk nilai rata-rata post-test, ulangan harian maupun hasil belajarnya. Hal ini menunjukkan bahwa kemampuan kognitif siswa kelas eksperimen lebih baik dibandingkan dengan kemampuan kognitif siswa kelas demonstrasi. Fenomena ini dapat dijelaskan dengan tingkat aktivitas belajar siswa dalam proses belajar mengajar.

Handhika (2010) mengungkapkan bahwa semakin besar frekuensi aktivitas belajar siswa, 
semakin banyak informasi yang diperolehnya untuk membangun pengetahuan yang lebih objektif. Jadi, siswa yang memiliki aktivitas tinggi akan memiliki hasil belajar yang lebih baik dari pada siswa yang memiliki aktivitas rendah. Pada pembelajaran dengan menggunakan metode eksperimen, siswa dapat memperhatikan secara teliti fenomena-fenomena yang terjadi pada saat praktikum berlangsung, dalam melakukan percobaan. Hal-hal yang menjadi pertanyaan siswa dapat terjawab dan kesalahan siswa dalam mengambil kesimpulan dapat dihindari melalui pengamatan dan pembuktian secara langsung dan mandiri. Selama kegiatan pembelajaran, siswa kelas eksperimen mampu menemukan dan memahami konsepnya secara mandiri sehingga membuat pondasi

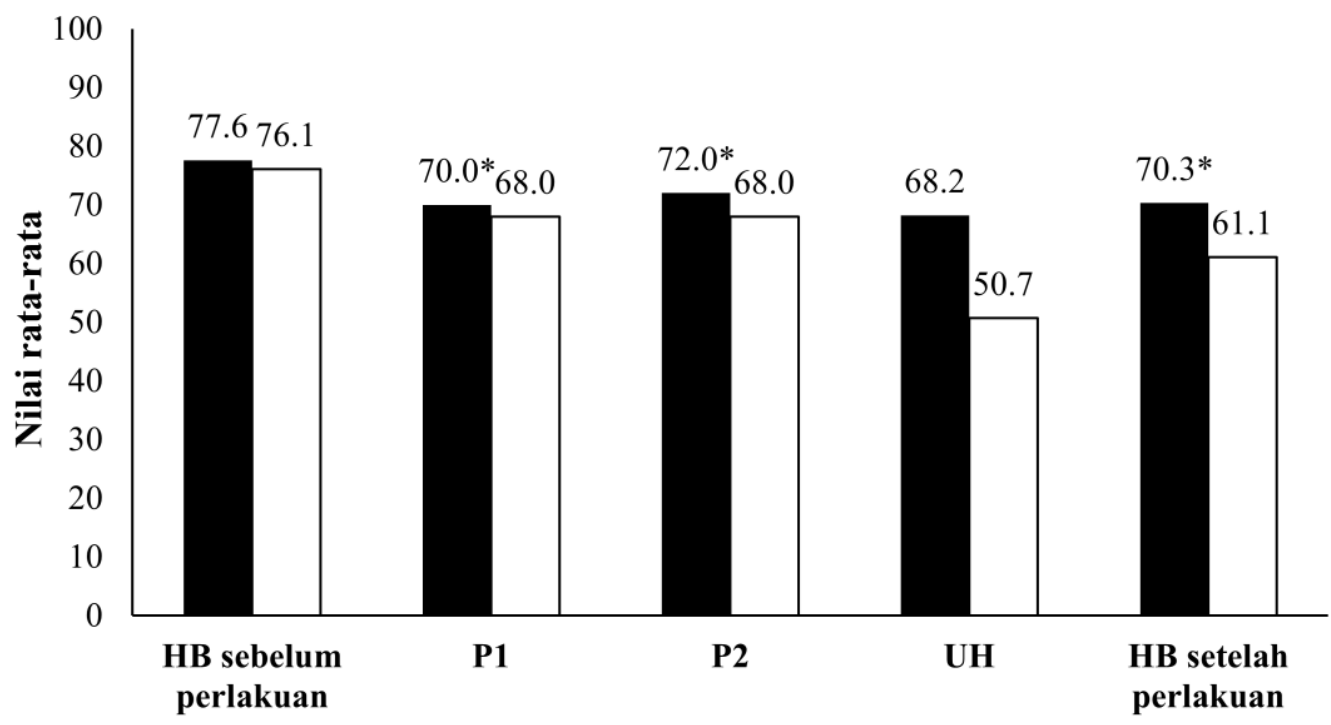

- Kelas X-1 (Kelas Eksperimen) $\quad$ Kelas X-2 (Kelas Demonstrasi)

*Berbeda dengan kelas demonstrasi pada taraf signifikan $(\alpha) 5 \%$

\section{Gambar 1. Rata-rata nilai siswa}

sementara pada pembelajaran dengan menggunakan metode demonstrasi, siswa tidak dapat mengamati secara rinci fenomena-fenomena yang terjadi pada saat demonstrasi berlangsung. Akibatnya kemampuan siswa di kelas demonstrasi lebih rendah dibandingkan dengan siswa kelas eksperimen dalam memahami materi yang dijelaskan oleh guru diawal pembelajaran.

Selama proses pembelajaran, antusias siswa dalam mengamati fenomena-fenomena yang terjadi pada saat demonstrasi cukup rendah dibanding dengan antusias siswa dalam mengamati fenomenafenomena yang terjadi pada saat melakukan eksperimen. Antusias siswa tergambar dalam aktivitas siswa dalam proses belajar mengajar. Aktivitas siswa pada kelas demonstrasi lebih rendah dibandingkan kelas eksperimen. Pada kelas eksperimen perhatian siswa terpusat sepenuhnya pada percobaan dikarenakan bebasnya siswa dalam melakukan hal yang belum pernah mereka kerjakan, memberikan pengalaman praktis yang dapat membentuk ingatan yang kuat dan keterampilan pemahaman konsep yang kuat. Penemuan dan pemahaman konsep secara mandiri dapat membuat daya ingat siswa terhadap konsep tersebut lebih lama dan lebih dalam. Hasil ini sesuai dengan penelitianpenelitian sebelumnya. Nuryani (2005) dan Nurdeli (2010) yang menyatakan bahwa metode eksperimen meningkatkan keyakinan siswa terhadap suatu hal, memperkaya pengalamannya, meningkatkan data ingatnya, mengembangkan sikap ilmiahnya dan meningkatkan prestasi belajarnya. Saregar dan sunarno (2013) menyatakan bahwa dengan metode eksperimen siswa lebih mudah dalam memahami konsep materi yang dipelajari dengan berdiskusi dan mengkomunikasikan masalah yang ditemui dengan teman kelompok masing-masing.

\section{SIMPULAN}

Berdasarkan hasil penelitian dapat disimpulkan bahwa terdapat perbedaan signifikan antara hasil belajar siswa yang diajar menggunakan model pembelajaran explicit instruction dengan metode eksperimen dan hasil belajar siswa yang diajar 
menggunakan model pembelajaran explicit instruction dengan metode demonstrasi pada pokok bahasan larutan elektrolit dan nonelektrolit di SMA Negeri 17 Samarinda. Hasil belajar siswa dengan menggunakan metode eksperimen lebih tinggi dibanding hasil belajar siswa dengan menggunakan metode demonstrasi.

\section{UCAPAN TERIMAKASIH}

Ucapan terima kasih dan penghargaan atas kerjasamanya kepada SMA Negeri 17 Samarinda yang telah mengijinkan penulis melaksanakan penelitian.

\section{DAFTAR PUSTAKA}

Ardana, P. W., Sunasih, N. W., \& Ganing, N. N. (2014). Penerapan model pembelajaran explicit instruction berbantuan media konkret untuk meningkatkan hasil belajar ipa siswa kelas VI SDN 17 Dangin Puri Kota Denpasar. Jurnal Mimbar PGSD Universitas Pendidikan Ganesha, 2(1).

Aritoanang, K. T. (2008). Minat dan motivasi dalam meningkatkan hasil belajar siswa. Jurnal Pendidikan Penabur, 7(10), 11-21.

Handhika, J. (2010). Pembelajaran fisika melalui inkuiri terbimbing dengan metode eksperimen dan demonstrasi ditinjau dari aktivitas dan perhatian mahasiswa. Jurnal Penelitian Pembelajaran Fisika, 1(1), 9-23.

Lestari, N., \& Kurjono. (2015). Pengaruh model explicit instruction terhadap hasil belajar pada mata pelajaran akuntansi di SMA Jatinagor. Jurnal Pendidikan Ilmiah, 2(1), 1-7.

Marjan, J., Arnayan, I. B., \& Setiawan, I. G. (2014). Pengaruh pembelajaran pendekatan saintifik terhadap hadil belajar biologi dan keterampilan proses sains siswa MA Mu'allimat NW Pancor Selong Kabupaten Lombok Timur Nusa Tenggara Barat. e-Journal Program Pascasarjana Universitas Pendidikan Ganesha, 4.

Marsita, R. A., Priatmoko, S., \& Kusuma, E. (2010). Analisis kesulitan belajar kimia siswa SMA dalam memahami materi larutan penyangga dengan menggunakan two-tier multiple choice diagnostic instrument. Jurnal Inovasi Pendidikan Kimia, 4(10).

Megawati. (2016). Penerapan model pembelajaran explicit instruction untuk meningkatkan hasil belajar siswa pada mata pelajaran IPA di kelas V SDN Ginunggung Tolitoli. Jurnal Tadulako Online, 4(10), 126-141.

Nurcholis. (2013). Implementasi metode penemuan terbimbing untuk meningkatkan hasil belajar siswa pada penarikan kesimpulan logika matematika. Jurnal Elektronik Pendidikan dan Matematika Tadulako, 1(1), 32-42.

Nurdeli. (2010). Pembelajaran fisika dengan pendekatan inkuiri terbimbing menggunakan metode eksperimen dan demonstrasi ditinjau dari kreativitas dan motivasi berprestasi. Surakarta: S2 Pendidikan Sains Universitas Sebelas Maret.

Nuryani. (2005). Strategi belajar mengajar biologi. Malang: UM Press.

Pramudjono. (2011). Statistika dasar (aplikasi untuk penelitian). Samarinda: Purry Kencana Mandiri.

Purwatiningsi, S. (2013). Penerapan metode penemuan terbimbing untuk meningkatkan hasil belajar siswa pada materi luas permukaan dan volume balok. Jurnal Elekteonik Pendidikan dan Matematika Tadulako, 1(1), 53-63.

Saregar, A., \& Sunarno, W. (2013). Pembelajaran fisika kontekstual melalui metode eksperimen dan demonstrasi diskusi menggunakan multimedia interaktif ditinjau dari sikap ilmiah dan kemampuan verbal siswa. Jurnal Inkuiri, 2(2), 100-113.

Sugiono. (2016). Metode penelitian pendidikan. Bandung: Alfabeta.

Sulistiani, C., \& Arif, S. (2015). Penggunaan model pembelajaran explicit instruction untuk meningkatkan prestasi belajar perawatan baterai siswa kelas $\mathrm{X}$ TKR SMK Negeri 1 Puring. Jurnal Pendidikan Otomotif, 6(1), 39-43.

Suroto. (2015). Penggunaan model pembelajaran explicit instruction dengan trainer PLC untuk meningkatkan prestasi belajar merakit sistem PL. Jurnal Pendidikan Teknologi dan Kejuruan, 22(3), 316-323. 
